\title{
PURIFICATION AND CHARACTERISATION OF ANGIOTENSIN I CONVERTING ENZYME (ACE) INHIBITORY PEPTIDE FROM BLOOD COCKLE (Anadara granosa) MEAT HYDROLYSATE
}

\author{
AISHAH SUHAIMI ${ }^{1}$, AMIZA MAT AMIN ${ }^{1 *}$, NORIZAH MHD SARBON ${ }^{1}$, \\ MOHD EFFENDY ABD. WAHID ${ }^{2}$ and ZALIHA HARUN ${ }^{1}$ \\ ${ }^{1}$ School of Food Science and Technology, Universiti Malaysia Terengganu, \\ 21030 Kuala Nerus, Terengganu, Malaysia \\ ${ }^{2}$ School of Fisheries and Aquaculture Sciences, Universiti Malaysia Terengganu, \\ 21030 Kuala Nerus, Terengganu, Malaysia \\ "E-mail: ama@umt.edu.my
}

Accepted 19 January 2020, Published online 30 June 2020

\begin{abstract}
Blood cockle (Anadara granosa) is the most abundant and available bivalves in Malaysia. Blood cockles meat has high protein content and has potential to generate bioactive peptides. To date, no study has been reported on purification and identification of angiotensin I converting enzyme (ACE) inhibitory peptides from blood cockle meat. Thus, the objectives of this study were to purify and characterize ACE inhibitory peptide from blood cockle meat hydrolysate. ACE inhibitory peptides from blood cockle meat hydrolysate $(\mathrm{CMH})$ were prepared by enzymatic protein hydrolysis using Protamex ${ }^{\circledR}$. Crude $\mathrm{CMH}$ was characterized for its stability against gastrointestinal proteases, at varying $\mathrm{pH}(2-11)$ and temperature $\left(4-90^{\circ} \mathrm{C}\right)$. Next, crude $\mathrm{CMH}$ was purified by ultrafiltration, ion exchange chromatography and reverse-phase chromatography and its amino acid sequence was identified. It was found that crude $\mathrm{CMH}$ was highly stable at low $\mathrm{pH}$ and temperature, and was resistant to gastrointestinal proteases (pepsin and trypsin). A three-step purification increased the inhibitory activity of $\mathrm{CMH}$, reducing its $\mathrm{IC}_{50}$ from $0.35 \mathrm{mg} / \mathrm{ml}$ to $0.0094 \mathrm{mg} / \mathrm{ml}$. The amino acid sequence of the purified peptide was determined as VNDLLSGSFKHFLY, with a molecular weight of $1621.88 \mathrm{Da}$. This study suggested the potential of ACE inhibitory peptide derived from cockle meat as a nutraceutical ingredient in functional food.
\end{abstract}

Key words: Blood cockle, angiotensin converting enzyme, peptide, hydrolysis

\section{INTRODUCTION}

Bioactive peptides offer potential physiological benefits to human gastrointestinal, nervous, cardiovascular and immune systems (Korhonen \& Pihlanto, 2006). For this reason, the purification and isolation of bioactive peptides from foods has aroused much interest in recent years. One such bioactive peptide is the angiotensin I converting enzyme (ACE) inhibitory peptide officially identified as angiotensin I converting enzyme (ACE, peptidyl dipeptide hydrolase, EC 3.4.15.1) inhibitor (Korhonen \& Pihlanto, 2006). ACE occurs naturally in cardiovascular system and it causes high blood pressure. ACE inhibitory peptide catalyzes the conversion of angiotensin I to the potent vasoconstrictor angiotensin II, inactivating

* To whom correspondence should be addressed. the vasodilator bradykinin and consequently reducing the blood pressure. Since the first discovery of an ACE inhibitor in snake venom, it has been extensively studied for pharmaceutical purposes, and synthetic variants such as captopril and enalapril, have become available (Ondetti, 1977). However, these synthetic ACE inhibitors incur adverse side effects such as mild azotemia at the start of therapy, hypotension, dizziness, renal dysfunction, non-productive cough, angioedema, hyperkalemia and renal insufficiency (Mann \& Chakinala, 2012). ACE inhibitors from natural foodderived protein sources are considered milder and safer than synthetically derived ACE inhibitors (Lee et al., 2010; Wu et al., 2015).

ACE inhibitory peptides are inactive within their parent proteins, but become active when liberated by enzymatic hydrolysis, fermentation or autolysis (García et al., 2013). ACE inhibitory 
peptides are commonly liberated by enzymatic hydrolysis, which is more easily controlled, requires a milder hydrolysis condition and yields a more uniform quality of hydrolysate than other methods (Liaset et al., 2000; He et al., 2013). The resulting peptides must resist complete hydrolysis by gastrointestinal proteases, and must pass through the intestinal wall while preserving their biological activity (Tavares et al., 2011). For application in food systems, functional peptides must also be robust to the various adversaries of food processing, such as alkaline, neutral or acidic conditions, and different ranges of temperature and storage time (Sánchez-Rivera et al., 2014). ACE inhibitory peptides are purified through a series of chromatographic separations, and typically contain 2-20 amino acid residues when fully isolated (Korhonen, 2009). Among the identified peptides are LKPNM from fish, LKP from oysters (Je et al., 2005), VLP and VLL from fresh water clams (Tsai et al., 2006) and VAP from grass carp (Chen et al., 2012).

Blood cockle (Anadara granosa) is an edible marine bivalve that is commercially cultured in the tidal mudflats of Southeast Asian region and known as a cheap protein source in Malaysia. The production of blood cockle dominates $87 \%$ of shellfish production, which account for 16,642 metric tonnes for the year of 2018 in Malaysia (Department of Fisheries Malaysia, 2018). After enzymatic hydrolysis in the lyophilized form, the protein content of raw cockle meat increased from $14 \%$ to $74 \%$ (Nurnadia et al., 2011). To date, studies on blood cockle hydrolysates have been limited to optimization of the enzymatic hydrolysis conditions of blood cockle meat for maximum degree of hydrolysis (Amiza \& Masitah, 2012), maximum ACE inhibitory activity (Aishah et al., 2017) and its wash water meat precipitate (Haslaniza et al., 2013). The purification and identification of ACE inhibitory peptides from blood cockle has not been reported. Thus, the present study aimed to purify and characterize ACE inhibitory peptides from blood cockle meat hydrolysate as a natural alternative to synthetic hypertension agents.

\section{MATERIALS AND METHODS}

\section{Materials}

Blood cockles (Anadara granosa) were sampled from a cultivated farm at Sungai Kerang, Perak, Malaysia. The whole cockles were cleaned, washed with tap water to remove mud and impurities, steamed $\left(30 \mathrm{~min}, 100^{\circ} \mathrm{C}\right)$ and manually deshelled to extract the meat. After homogenization in a food processor, the cockle meat was sealed in polyethylene bags and immediately frozen at $-40^{\circ} \mathrm{C}$ until required. Determination of crude protein content of blood cockle meat using Kjeldahl method found that it contained $14.58 \%$ crude protein. Protamex ${ }^{\mathrm{TM}}$ was purchased from Novo Nordisk A/S Co. (Bagsvaerd, Denmark). Analyticalgrade angiotensin I converting enzyme (EC 3.4.15.1) from rabbit lung, hippuryl-histidyl-leucine (HHL), and other proteases and reagents were purchased from Sigma Chemical Co. (St. Louis, MO, USA).

\section{Preparation of ACE inhibitory peptides from blood cockle meat hydrolysate (CMH)}

$\mathrm{CMH}$ was prepared by enzymatic hydrolysis using commercial food grade proteinase Protamex ${ }^{\mathrm{TM}}$, as described by Aishah et al. (2017). The hydrolysis mixture was then centrifuged at $4^{\circ} \mathrm{C}$ and $4000 \mathrm{rpm}$ for $20 \mathrm{~min}$. The resulting supernatant was lyophilized and stored in an airtight container at $-20^{\circ} \mathrm{C}$ for future use.

\section{ACE inhibitory activity assay}

ACE inhibitory activity was determined by the method of Cushman and Cheung (1971), which measures the concentration of hippuric acid liberated from HHL. The detailed assay was described by Aishah et al. (2017). The ACE inhibitory activity $(\%)$ was calculated as $\left(\mathrm{A}_{\mathrm{c}}-\mathrm{A}_{\mathrm{s}}\right) /$ $\left(A_{c}-A_{b}\right) \times 100$, where $A_{c}, A_{s}$ and $A_{b}$ are the absorbances of the control, sample and blank, respectively. The half maximal inhibitory concentration $\left(\mathrm{IC}_{50}\right)$ was calculated as the concentration of the hydrolysate that provided $50 \%$ inhibition of ACE activity under the assay conditions. It can be determined by regression analysis of ACE inhibitory activity (\%) versus hydrolysate concentration $(\mathrm{mg} / \mathrm{ml}$ ) (Tsai et al., 2006).

\section{Effect of temperature, $\mathrm{pH}$ and gastrointestinal proteases on ACE inhibitory activity in crude $\mathrm{CMH}$}

To determine the effect of temperature on ACE inhibitory activity in crude $\mathrm{CMH}$, it was incubated at different temperatures $\left(4,25,37\right.$ and $\left.90^{\circ} \mathrm{C}\right)$ and stored for various times $(0.5-3.5 \mathrm{~h})$. The effect of $\mathrm{pH}$ on ACE inhibitory activity in crude $\mathrm{CMH}$ was assessed by adjusting the peptide solution to $\mathrm{pH} 2$, $\mathrm{pH} 8$ or $\mathrm{pH} 11$ with $1 \mathrm{~N} \mathrm{HCl}$ or $\mathrm{NaOH}$, and incubating at $25^{\circ} \mathrm{C}$ for various times $(0.5-3.5 \mathrm{~h})(\mathrm{Qu}$ et al., 2010).

To simulate the enzymatic conditions in the human stomach and intestines, crude $\mathrm{CMH}$ was treated with pepsin and trypsin enzymes. Control sample (T0) was crude CMH solution $(10 \mathrm{mg} / \mathrm{ml})$ without any enzyme treatment. T1 sample was crude $\mathrm{CMH}$ solution $(10 \mathrm{mg} / \mathrm{ml})$ after treatment with pepsin $(1: 50 \mathrm{w} / \mathrm{w})\left(\mathrm{pH} 2.0,37^{\circ} \mathrm{C}, 2 \mathrm{~h}\right)$ whereas $\mathrm{T} 2$ represent crude $\mathrm{CMH}$ solution $(10 \mathrm{mg} / \mathrm{ml})$ after treatment with pepsin $\left(1: 50 \mathrm{w} / \mathrm{w}\left(\mathrm{pH} 2.0,37^{\circ} \mathrm{C}\right.\right.$, $2 \mathrm{~h})$ followed by treatment with trypsin $(1: 25 \mathrm{w} / \mathrm{w})$ 
( $\left.\mathrm{pH} 8.0,37^{\circ} \mathrm{C}, 4 \mathrm{~h}\right)$. Finally, the sample was inactivated at $95^{\circ} \mathrm{C}$ and cooled to room temperature prior to determining its ACE inhibitory activity (Quirós et al., 2009).

\section{Purification of crude CMH by ultrafiltration, ion exchange and RP-HPLC}

Purification of ACE inhibitory peptide from crude $\mathrm{CMH}$ was purified as described by Ko et al. (2012).

\section{Ultrafiltration}

Crude CMH $(50 \mathrm{mg} / \mathrm{ml})$ with $\mathrm{IC}_{50}$ of $0.35 \mathrm{mg} /$ $\mathrm{ml}$ was fractionated through a series of ultrafiltration membranes (Sartorious Stedim Biotech GmbH, Germany) with molecular weight cut-offs (MWCOs) of $10 \mathrm{kDa}, 5 \mathrm{kDa}$ and $3 \mathrm{kDa}$. The four resulting peptide fractions ( $<10 \mathrm{kDa}, 10-5 \mathrm{kDa}, 3-5 \mathrm{kDa}$ and $<3 \mathrm{kDa}$ ) were lyophilized and assayed for their ACE inhibitory activity.

\section{Ion exchange chromatography}

The ultrafiltration fraction with the highest ACE inhibitory activity was subjected to further purification through a HiPrep 16/10 DEAE FF anion exchange column (GE Healthcare) using an AKTA purifier system (GE Healthcare, Uppsala, Sweden) at a concentration of $20 \mathrm{mg} / \mathrm{ml}$. The column was equilibrated with 5 column volumes of $20 \mathrm{mM}$ sodium acetate buffer $(\mathrm{pH} 4)$. The sample was then injected and eluted at a linear gradient of $2 \mathrm{M} \mathrm{NaCl}$ $(0-30 \%)$ in the same buffer at a flow rate of 60 $\mathrm{ml} / \mathrm{h}$. The absorbance eluent was monitored at 280 $\mathrm{nm}$. The fraction was collected to a volume of 10 $\mathrm{ml}$, desalted and lyophilized before its ACE inhibitory activity was determined.

\section{Reverse-phase high performance liquid chromato- graphy (RP-HPLC)}

The peptide fraction $(10 \mathrm{mg} / \mathrm{ml})$ exhibiting the highest ACE inhibitory activity was further purified by RP-HPLC on a Gemini-NX $10 \mu \mathrm{m} \mathrm{C}_{18}$ column $(21.2 \times 250 \mathrm{~mm}$, Phenomenex Co. Ltd., Torrance, CA, USA). The column was pre-equilibrated with Milli-Q water for $10 \mathrm{~min}$ and the sample was eluted under a linear gradient of acetonitrile (0-50\%), applied for $20 \mathrm{~min}$ at a flow rate of $2 \mathrm{ml} / \mathrm{min}$ (monitored at $215 \mathrm{~nm}$ ). The active peak representing the highest ACE inhibitory activity was pooled and lyophilized immediately.

\section{Identification of amino acid sequence and molecular mass of purified peptide}

The molecular mass and amino acid sequence of the purified peptide was analysed by electrospray ionization mass spectrometry using the Shimadzu Prominence nano HPLC system coupled to a 5600 Triple TOF mass spectrometer (AB Sciex). Peptide sample was loaded onto an Agilent Zorbax 300SBC18, $3.5 \mu \mathrm{m}$ (Agilent Technologies) and separated with a linear gradient of water/ acetonitrile $/ 0.1 \%$ formic acid $(\mathrm{v} / \mathrm{v})$. The sequence information from the resulting MS/MS spectra was analysed using PEAKS Studio Version 4.5 SP2 (Bioinformatic Solutions) and manual interpretation.

\section{RESULTS AND DISCUSSION}

Effect of temperature, $\mathrm{pH}$ and gastrointestinal proteases on ACE inhibitory activity in crude $\mathrm{CMH}$

The stability of ACE inhibitory activity in crude $\mathrm{CMH}$ was tested under different temperatures and $\mathrm{pH}$ values, and in the presence of various gastrointestinal proteases at various storage times (Figure 1(a)-(c)).

It was found that $\mathrm{CMH}$ maintained high $\mathrm{ACE}$ inhibitory activity under all temperature treatments for $30-60 \mathrm{~min}$, and at $4^{\circ} \mathrm{C}$ and $25^{\circ} \mathrm{C}$ for the maximum tested storage time $(3.5 \mathrm{~h})$. $\mathrm{CMH}$ also retained more than $50 \%$ of its initial activity at $37^{\circ} \mathrm{C}$, but its activity significantly degraded at $90^{\circ} \mathrm{C}$, indicating that $\mathrm{CMH}$ was more stable at low temperatures than at higher temperatures. Reduction in ACE inhibitory activity after heat treatment could be due to hydrolysis of peptide bonds, alteration of peptide sequences resulting in changes of hydrolysate properties, hydrophobic interaction and aggregation of their structure (Meisel, 1998; La Fuente et al., 2002). Peptides from P. yezeonsis seaweed tested at similar storage times exhibited the same trend i.e: high ACE inhibitory activity at $4^{\circ} \mathrm{C}$ and $25^{\circ} \mathrm{C}$, but reduced activity at higher temperatures and longer storage times. After $3.5 \mathrm{~h}$ storage at $90^{\circ} \mathrm{C}$, the $P$. yezeonsis peptides had lost approximately $53.4 \%$ of their initial activity. Peptides from tuna cooking juice (Hwang, 2010) and soy protein (Wu \& Ding, 2002) were more stable to high temperature whereby peptides from both samples were strongly resistant to $2 \mathrm{~h}$ storage at $20-100^{\circ} \mathrm{C}$.

The effect of $\mathrm{pH}$ was also evaluated over the same storage times (0.5-3.5 h) (Figure 1(b)). At pH 2 and $8, \mathrm{CMH}$ remained highly stable after $1.5 \mathrm{~h}$. The ACE inhibitory activity of the peptides from blood cockle was better preserved in acidic than in alkaline environments. Similar finding has been reported for ACE inhibitory activity from $P$. yezeonsis exposed to $\mathrm{pH}$ levels of 2.0, 8.0 and 11.0 reduced from its initial value by $9.5 \%, 29.5 \%$ and $59.7 \%$, respectively. The high stability of peptides under different processing conditions is important from a practical viewpoint, because the target food systems are usually processed with many steps with different $\mathrm{pH}$, temperatures and durations. Stable peptides should retain their bioactivity during these 


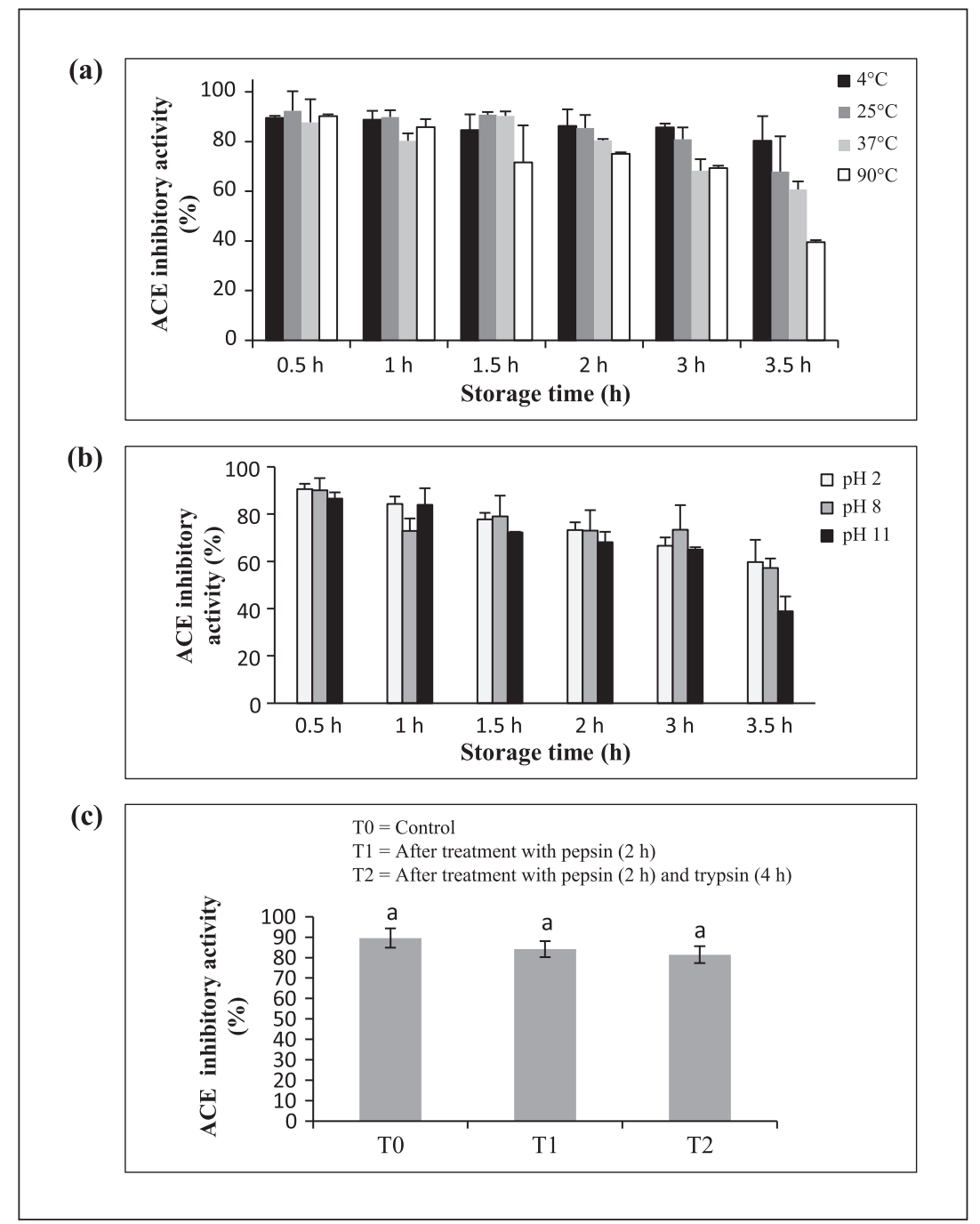

Fig. 1. Stability of ACE inhibitory activity of $\mathrm{CMH}$ (a) at various storage times and temperatures, (b) at various storage times and $\mathrm{pH}$ and (c) following enzymatic treatments with gastrointestinal proteases.

processes. Besides the processing conditions, the bioactivity of a peptide depends on the composition of the food matrix and the bioactive peptide structure (López-Fandiño et al., 2006).

Figure 1(c) shows the effect of gastrointestinal proteases on the ACE inhibitory activity of $\mathrm{CMH}$. The ACE inhibitory activities under the control treatment (without proteases) and treatments $\mathrm{T} 1$ and T2 were $89.56 \%, 84.09 \%$ and $81.44 \%$, respectively. These results indicate that $\mathrm{CMH}$ was relatively stable against gastrointestinal proteases (the differences among treatments were insignificant; $p>0.05)$. ACE inhibitory peptides from other protein sources such as algae $(\mathrm{Qu}$ et al., 2010) and dry-cured ham (Escudero et al., 2014) are also stable to digestion with gastrointestinal proteases. Human gastrointestinal digestion proceeds by physical and chemical processes involving proteases at appropriate $\mathrm{pH}$ before absorption occurs (Langerholc et al., 2011).

\section{Purification of ACE inhibitory peptide from crude CMH using ultrafiltration, ion exchange and $R P$ HPLC}

Blood cockle meat was subjected to enzymatic hydrolysis by Protamex ${ }^{\circledR}$ and fractionated through a series of ultrafiltration membranes resulting in 4 fractions with different molecular weight cut-offs (>10 kDa, 10-5 kDa, 5-3 kDa and $<3 \mathrm{kDa}$ ). The lyophilized fraction with $<3 \mathrm{kDa}$ MWCO gave the highest percentage of weight as compared to other UF fractions (36.92\%), indicating the highest peptide recovery in that fraction. The lyophilized fraction with $>10 \mathrm{kDa}$ MWCO gave the second highest percentage of weight $(12.18 \%)$, followed by lyophilized fraction with 5-10 kDa MWCO (0.68\%) and finally lyophilized fraction with $3-5 \mathrm{kDa}$ MWCO $(0.46 \%)$. This finding is similar to other studies whereby $<3 \mathrm{kDa}$ UF hydrolysate fraction contained highest ACE inhibitory activity (Du et al., 2013; Rho et al., 2009). Moreover, it exhibited the 
Table 1. Recovery, $I C_{50}$ and ACE inhibitory activities of ultrafiltration fractions from blood cockle hydrolysate

\begin{tabular}{cccc}
\hline CMH fractions & $\begin{array}{c}\text { Recovery } \\
(\%)\end{array}$ & $\begin{array}{c}\mathrm{IC}_{50} \text { value } \\
(\mathrm{mg} / \mathrm{ml})\end{array}$ & $\begin{array}{c}\text { ACE inhibitory activity } \\
(\%)\end{array}$ \\
\hline$<3 \mathrm{kDa}$ & $36.92 \%$ & $0.27 \pm 0.027$ & $91.75 \pm 7.81$ \\
$3-5 \mathrm{kDa}$ & $5.64 \%$ & $0.46 \pm 0.020$ & $82.29 \pm 0.54$ \\
$5-10 \mathrm{kDa}$ & $6.34 \%$ & $0.68 \pm 0.013$ & $71.74 \pm 4.22$ \\
$>10 \mathrm{kDa}$ & $12.18 \%$ & $0.60 \pm 0.007$ & $81.92 \pm 2.33$ \\
\hline
\end{tabular}

highest ACE inhibitory activity among the fractions, with an $\mathrm{IC}_{50}$ of $0.27 \mathrm{mg} / \mathrm{ml}$ (Table 1). These results confirmed the presence of peptides with high ACE inhibitory activity; moreover, these peptides were concentrated in the low molecular weight fraction as reported by Ko et al. (2012) for Styela clava hydrolysate, Lee et al. (2010) for frame protein hydrolysate, Tsai et al. (2006) for freshwater clam hydrolysate. High ACE inhibitory activity by low molecular weight peptide fractions $(<10 \mathrm{kDa})$ could be due to the presence of a high amount of hydrophobic amino acids (i.e. Gly, Val, Ala, Pro and Leu) that concentrate in these fractions which have the binding ability to both $\mathrm{N}$-terminal and $\mathrm{C}$ terminal of ACE, thus better for inhibition ACE activity (Korhonen \& Pihlanto, 2003; Ketnawa \& Rawdkuen, 2013).

Peptides $(3 \mathrm{kDa})$ were purified on a HiPrep16/ 10 anion exchange column with a linear gradient of $\mathrm{NaCl}(0-2 \mathrm{M})$ and separated into a nonadsorptive portion of an unbound protein followed by three adsorptive portions of bound proteins (Fr-1, Fr-2 and Fr-3), as shown in Fig. 2(a). The three bound fractions (Fr-1, Fr-2 and Fr-3) were eluted from $0.2-0.3 \mathrm{M} \mathrm{NaCl}$ and assayed for $\mathrm{ACE}$ inhibitory activity (refer Fig. 2(b)). The highest activity was exhibited by Fr-2 (86.45\% at $0.1 \mathrm{mg} /$ $\mathrm{ml}$ ). Ion exchange chromatography selectively isolates ACE inhibitory peptide based on charge (Ketnawa \& Rawdkuen, 2013). This technique is widely used to purify ACE inhibitory peptides from food protein sources such as tuna frame (Lee et al., 2010) and the skin gelatine of Pacific cod (Moskowitz, 2003). The reported ACE inhibitory activities of tuna frame protein and Pacific cod skin gelatine were $76.4 \%$ at $2 \mathrm{mg} / \mathrm{ml}$ and $71.81 \%$ at 0.1 $\mathrm{mg} / \mathrm{ml}$, respectively. In both studies, all potent peptides were eluted in the range $0.2-0.6 \mathrm{M} \mathrm{NaCl}$. Other studies have sorted ACE inhibitory peptides by molecular size through gel filtration columns using distilled water for example the oyster sauce (Je et al., 2005). Alternatively, Jung et al. (2006) filtered the frame protein from yellowfin sole through an SP-Sephadex C-25 ion exchange column and they eluted the potent peaks in the range of $1.4-1.5 \mathrm{M} \mathrm{NaCl}$.
After further purification of $\mathrm{Fr}-2$ on an HPLC column, a single peak was obtained at $18 \%$ acetonitrile. This peak was isolated and tested for ACE inhibitory activity (Fig. 2(c)). The isolated peak exhibited higher activity than the isolates separated in the previous steps (ultrafiltration and ion exchange chromatography), with an $\mathrm{IC}_{50}$ of $0.0094 \pm 0.0006 \mathrm{mg} / \mathrm{ml}$. The refined isolate was characterized by LC-MS/MS. ACE inhibitory peptides have been isolated from other food protein sources, such as fermented oyster sauce with an $\mathrm{IC}_{50}$ of $0.0874 \mathrm{mg} / \mathrm{ml}$ (Je et al., 2005), yellowfin sole frame protein with an $\mathrm{IC}_{50}$ of $0.0287 \mathrm{mg} / \mathrm{ml}$ (Jung et al. 2006) and from sea bream scales (Fahmi et al., 2004), salmon skin (Gu et al., 2011) and fermented anchovy, sardine and bonito sauce (Ichimura et al., 2003) with $\mathrm{IC}_{50}$ s ranging from 0.003 to 0.332 $\mathrm{mg} / \mathrm{ml}$. In previous studies, the purified peptides were usually eluted from 5\%-20\% acetonitrile, depending on the precise distribution of the hydrophobic residues in each species and the preliminary purification steps (ultrafiltration, ion exchange or gel filtration) (Lee et al., 2010; Himaya et al., 2012; Jung et al., 2006; Qian et al., 2007; Tsai et al., 2008). As the acetonitrile concentration increased, each analyte reached its critical value, desorbed from the hydrophobic stationary-phase surface and eluted from the column into the flowing mobile phase (Segura-Campos et al., 2011).

\section{Identification of purified CMH using LC-MS/MS}

The RP-HPLC purified fraction was determined using LC-MS/MS analysis coupled with databaseassisted sequence matching. Figure 3 shows relative intensity (\%) versus mass. The deduced sequence of the peptides was presented as $\mathrm{b}$ and $\mathrm{y}$ ions. From the figure, the RP-HPLC purified fraction was composed of 14 amino acid residues: Val-Asn-AspLeu-Leu-Ser-Gly-Ser-Phe-Lys-His-Phe-Leu-Tyr (VNDLLSGSFKHFLY; MW 1621.88 Da) with an aliphatic amino acid (valine) at the N-terminal, and hydrophobic residues (leucine, valine) and aromatic amino acids (tyrosine, phenylalanine) at the Cterminal. This sequence was the ACE inhibitory peptides with various sequences have been derived 


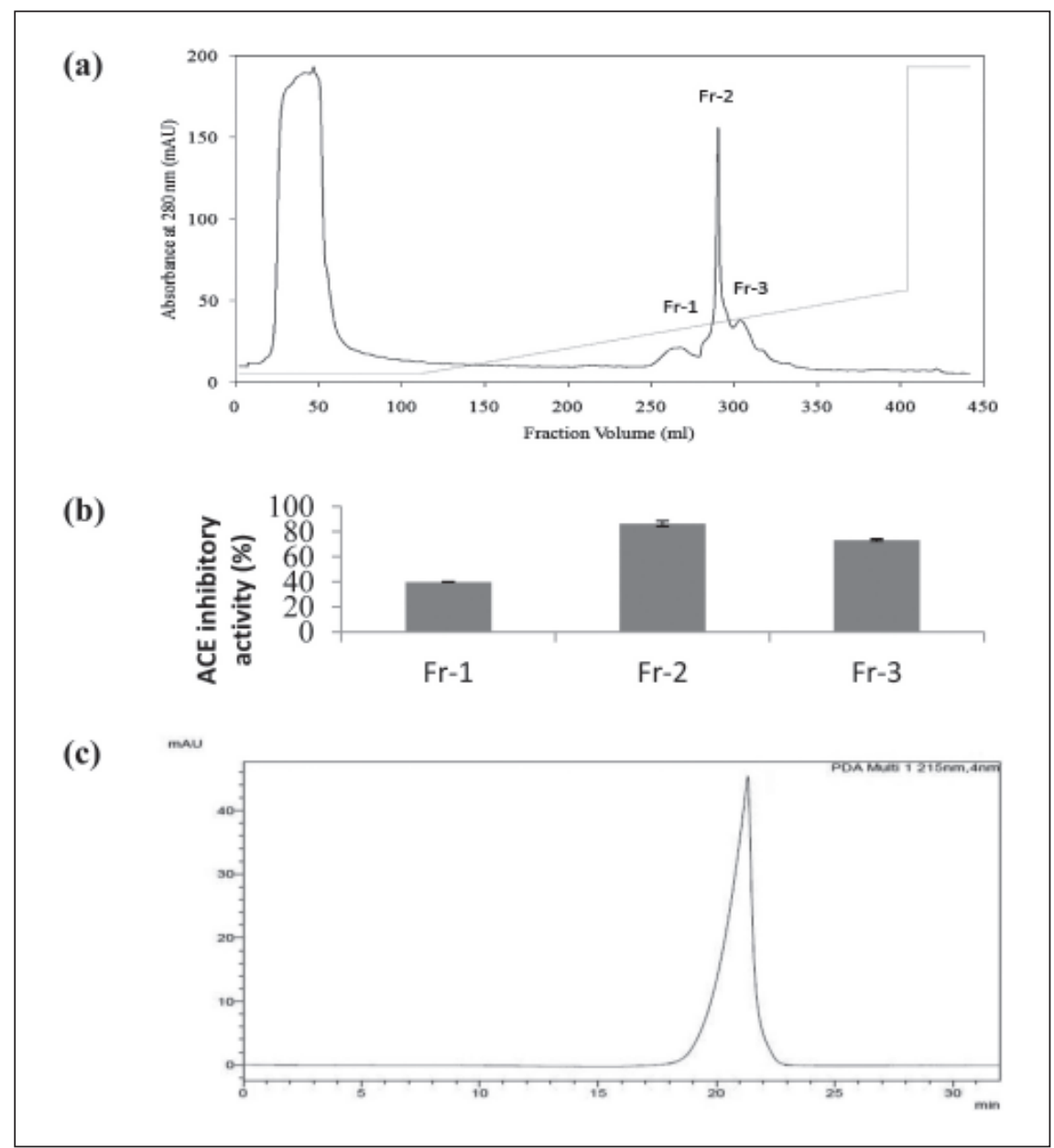

Fig. 2. (a) HiPrep 16/10 DEAE FF anion exchange chromatogram of the $<3 \mathrm{kDa}$ fraction separated under a linear gradient of $\mathrm{NaCl}$ (b) ACE inhibitory activity of the fraction separated by an ion exchange column (c) RP-HPLC chromatogram after eluting Fr-2 with a linear gradient of acetonitrile.
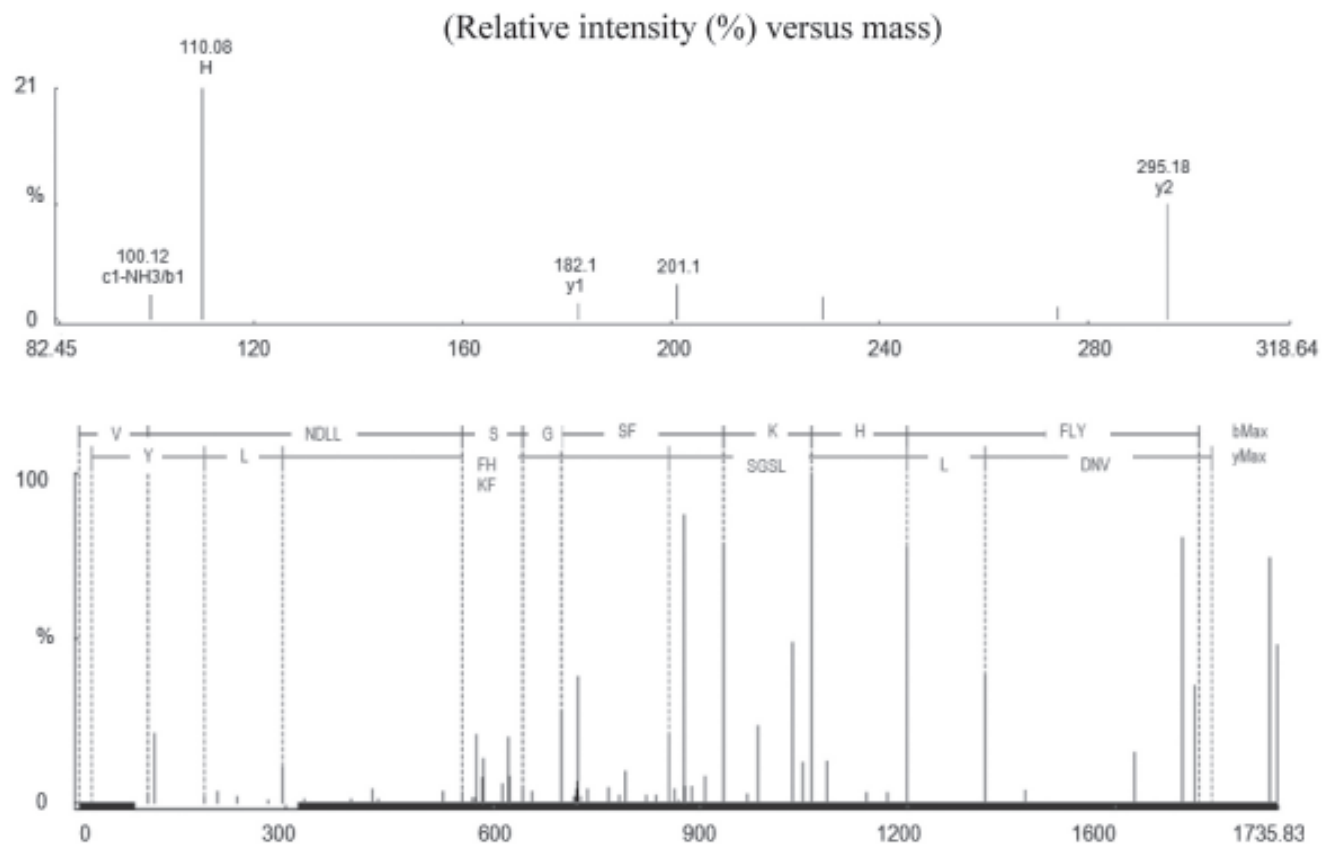

Fig. 3. De novo spectra of purified ACE inhibitory peptide from crude CMH characterized by LC-MS/MS at m/z 820.42. 
from food proteins, but to our knowledge, have not been previously isolated from blood cockle. Among the previous reports of isolated ACE inhibitory peptides are LKPNM and LKP from oyster (Je, 2005), MIFGAGGPEL from yellowfin sole frame (Jung et al., 2006), VLP and VLL from fresh water clams (Tsai et al., 2008), VAP from grass carp (Chen et al., 2012) and LPGRPPIKPWPL from walnut (Wang et al., 2014). Most of the reported ACEI peptides are short peptides composed of 3-20 amino acid residues (Qian et al., 2007; Tsai et al., 2008). According to Pihlanto (2000), the most potent and specific peptide inhibitors have similar structures and their ACE activities are strongly influenced by the C-terminal sequence, which generally possesses a proline or aromatic residue. Conversely, their N-terminals usually contain hydrophobic amino acid residues. Among the N-terminal amino acids, the branched-chain aliphatic amino acids such as Ile and Val predominate (Cheung et al., 1980).

In this study, the isolated peptide from blood cockle meat is composed of 14 amino acid residues (VNDLLSGSFKHFLY). This peptide is considered long where its structural feature is important in determining ACE inhibitory potency. The presence of Tyr at the C-terminal of the isolated ACE inhibitory peptide from blood cockle meat could be the potential contributor to high ACE inhibitory activity (Aluko, 2012). According to Iwaniak et al. (2014), long chain ACE inhibitory peptides other than dipeptide and tripeptide usually possess of basic amino acids (Arg, Lys) at the C-terminal end. For long peptides, which consist of more than 4 amino acid residues, the type and arrangement of the last four amino acid residues at the $\mathrm{C}$-terminal play role in determining their ACE inhibitory potency. The potential contributor to their ACE inhibitory potency are the presence of tyrosine and cysteine at the $\mathrm{C}$-terminal position or histidine, tryptophan and methionine at the penultimate $\mathrm{C}$-terminal position, the presence of isoleucine, leucine, valine and methionine at the $\mathrm{C} 3$ position or tryptophan at the $\mathrm{C} 4$ position of long chain ACE inhibitory peptides (Aluko, 2012). A run on BIOPEP database showed that no amino acid sequence has been reported before similar to this cockle-derived ACE inhibitory peptide. It was also found that four dipeptide sequence with potential ACE inhibitory activity was encrypted in the amino acid sequence of cockle-derived ACE inhibitory peptide, namely LY, GS, SG and SF. Aluko (2012) also reported a long chain ACE inhibitory peptide with 21 amino acid residues (GDLGKTTTVSNWSPPKYKDTP) from tuna frame hydrolysate.

\section{CONCLUSION}

Crude $\mathrm{CMH}$ was found to be stable against various gastrointestinal proteases at low $\mathrm{pH}(\mathrm{pH} 2)$ and temperature $\left(4^{\circ} \mathrm{C}\right)$, but was sensitive to higher $\mathrm{pH}$, higher temperatures and longer storage times. After a three-step purification, a potent ACE inhibitory peptide (VNDLLSGSFKHFLY) was isolated from blood cockle. The $\mathrm{IC}_{50}$ was improved from $0.35 \mathrm{mg} /$ $\mathrm{ml}$ in the crude sample to $0.0094 \mathrm{mg} / \mathrm{ml}$ in the pure isolate. This finding suggests that blood cockle meat hydrolysate is a potent source of ACE inhibitory peptides.

\section{ACKNOWLEDGEMENTS}

This research was financially supported by the escience fund under the Malaysia Ministry of Science, Technology and Innovation (MOSTI). Aishah Suhaimi acknowledges that her MSc tuition fee was sponsored by Ministry of Higher Education, Malaysia.

\section{REFERENCES}

Aluko, R.E. 2012. Functional Foods and Nutraceuticals. Springer Verlag. New York. p. 37-49.

Aishah, S., Amiza, M.A., Sarbon, N.M. \& Effendy, W.A.M. 2017. Optimization of enzymatic protein hydrolysis conditions on Angiotensinconverting enzyme inhibitory (ACEI) activity from blood cockle (Anadara granosa) meat. International Food Research Journal, 24(2): 565-570.

Amiza, M.A. \& Masitah, M. 2012. Optimization of enzymatic hydrolysis of blood cockle (Anadara granosa) using Alcalase ${ }^{\circledR}$. Borneo Science, 31: 1-10.

Chen, J., Wang, Y., Zhong, Q., Wu, Y. \& Xia, W. 2012. Purification and characterisation of a novel angiotensin-I converting enzyme (ACE) inhibitory peptide derived from enzymatic hydrolysate of grass carp protein. Peptides, 33: 52-58.

Cheung, H.-S., Wang, F.-L., Ondetti, M.A., Sabo, E.F. \& Cushman, D.W. 1980. Binding of peptide substrates and inhibitors of angiotensin converting enzyme. The Journal of Biological Chemistry, 255: 401-407. 
Cushman, D.W. \& Cheung, H.S. 1971. Spectrophotometric assay and properties of the angiotensin-converting enzyme of rabbit lung. Biochemical Pharmacology, 20(7): 1637-48.

Department of Fisheries Malaysia (DOFM). 2015 Annual fisheries statistics book 2015. Department of Fisheries Malaysia. Putrajaya. Retrieved on 12.12.16, from Department of Fisheries Malaysia Official Portal: http:// www.dof.gov.my/

Du, L., Fang, M., Wu, H., Xie, J., Wu, Y., Li, P. \& Wei, D. 2013. A novel angiotensin I-converting enzyme inhibitory peptide from Phascolosoma esculenta water-soluble protein hydrolysate. Journal of Functional Foods, 5(1): 475-483.

Escudero, E., Mora, L. \& Toldrá, F. 2014. Stability of ACE inhibitory ham peptides against heat treatment and in vitro digestion. Food Chemistry, 161: 305-311.

Fahmi, A., Morimura, S., Guo, H.C., Shigematsu, T., Kida, K. \& Uemura, Y. 2004. Production of angiotensin I converting enzyme inhibitory peptides from sea bream scales. Process Biochemistry, 39: 1195-1200.

García, M.C., Puchalska, P., Esteve, C. \& Marina, M.L. 2013. Vegetable foods: a cheap source of proteins and peptides with antihypertensive, antioxidant, and other less occurrence bioactivities. Talanta, 106: 328-49.

Gu, R.-Z., Li, C.-Y., Liu, W.-Y., Yi, W.-X. \& Cai, M.-Y. 2011. Angiotensin I-converting enzyme inhibitory activity of low-molecular-weight peptides from Atlantic salmon (Salmo salar L.) skin. Food Research International, 44(5): 15361540 .

Haslaniza, H., Maskat, M.Y., Wan Aida, W.M., Mamot, S. \& Saadiah, I. 2013. Optimisation of enzymatic hydrolysis of cockle (Anadara granosa) meat wash water precipitate for the development of seafood flavour. International Food Research Journal, 20(6): 3053-3059.

He, S., Franco, C. \& Zhang, W. 2013. Functions, applications and production of protein hydrolysates from fish processing. Food Research International, 50(1): 289-297.

Himaya, S.W.A., Ngo, D.-H., Ryu, B. \& Kim, S.-K. 2012. An active peptide purified from gastrointestinal enzyme hydrolysate of Pacific cod skin gelatine attenuates angiotensin-I converting enzyme (ACE) activity and cellular oxidative stress. Food Chemistry, 132: 18721882.

Hwang, J.S. 2010. Impact of processing on stability of angiotensin I-converting enzyme (ACE) inhibitory peptides obtained from tuna cooking juice. Food Research International, 43: 902906.
Ichimura, T., Hu, J., Aita, D.Q. \& Maruyama, S. 2003. Angiotensin I-converting enzyme inhibitory activity and insulin secretion stimulative activity of fermented fish sauce. Journal of Bioscience and Bioengineering, 96: 496-499.

Iwaniak, A., Minkiewicz, P. \& Darewicz, M. 2014. Food-originating ACE inhibitors, including antihypertensive peptides, as preventive food components in blood pressure reduction. Comprehensive Reviews in Food Science and Food Safety, 13: 114-134.

Je, Y.J., Park, J.Y., Jung, W.K. \& Kim, S.K. 2005. Isolation of angiotensin I converting enzyme (ACE) inhibitor from fermented oyster sauce, Crassostrea gigas. Food Chemistry, 90: 809814.

Jung, W.K., Mendis, E., Je, J.-Y., Park, P.-J., Son, B.W. \& Kim, H.C. 2006. Angiotensin Iconverting enzyme inhibitory peptide from yellowfin sole (Limanda aspera) frame protein and its antihypertensive effect in spontaneously hypertensive rats. Food Chemistry, 94(1): 26-32.

Ketnawa, S. \& Rawdkuen, S. 2013. Purification and characterisation of ACE inhibitory peptide from aquatic resources: a review. International Journal of Plant, Animal and Environmental Sciences, 3: 220-233.

Ko, S.C., Lee, J.K., Byun, H.G., Lee, S.C. \& Jeon, Y.J. 2012. Purification and characterisation of angiotensin I-converting enzyme inhibitory peptide from enzymatic hydrolysates of Styela clava flesh tissue. Process Biochemistry, 47: 3440.

Korhonen, H. 2009. Milk-derived bioactive peptides: From science to applications. Journal of Functional Food, 1: 177-187.

Korhonen, H. \& Pihlanto, A. 2006. Bioactive peptides: Production and functionality. International Dairy Journal, 16(9): 945-960.

Korhonen, H. \& Pihlanto, A. 2003. Bioactive peptides: Novel applications for milk proteins. Applied Biotechnology, Food Science and Policy, 1: 133-144.

La Fuente, M.A., Hemar, Y., Tamehana, M., Munro, P.A. \& Singh, H. 2002. Process-induced changes in whey proteins during the manufacture of whey protein concentrates. International Dairy Journal, 12: 361-369.

Langerholc, T., Maragkoudakis, P.A., Wollgast, J., Gradisnik, L. \& Cencic, A. 2011. Novel and established intestinal cell linemodels-An indispensable tool in food science and nutrition. Trends in Food Science and Technology, 22: 11-20. 
Lee, S.-H., Qian, Z.-J. \& Kim, S.-K. 2010. A novel angiotensin I converting enzyme inhibitory peptide from tuna frame protein hydrolysate and its antihypertensive effect in spontaneously hypertensive rats. Food Chemistry, 118: 96-102.

Liaset, B., Lied, E. \& Espe, M. 2000. Enzymatic hydrolysis of by-products from the fish-filleting industry; chemical characterisation and nutritional evaluation. Journal of the Science of Food and Agriculture, 80: 581-589.

López-Fandiño, R., Otte, J. \& van Camp, J. 2006. Physiological, chemical and technological aspects of milk-protein-derived peptides with antihypertensive and ACE-inhibitory activity. International Dairy Journal, 16: 1277-1293.

Mann, D.G. \& Chakinala, M. 2012. Heart Failure and Cor Pulmonale. Harrinson's Principle of Internal Medicine. Longo et al. (Eds.). Mc Graw-Hill Companies, Inc. USA. p. 1909.

Meisel, H. 1998. Overview on milk protein-derived peptides. International Dairy Journal, 8: 363373.

Moskowitz, D.W. 2003. Is 'somatic' angiotensin Iconverting enzyme a mechanosensor? Diabetes Technology and Therapeutics, 4: 841-85.

Nurnadia, A.A., Azrina, A. \& Amin, I. 2011. Proximate composition and energetic value of selected marine fish. International Food Research Journal, 18: 137-148.

Ondetti, M.A. 1977. Design of specific inhibitors of angiotensin converting enzyme: new class of orally active antihypertensive agents. Science, 196: 441-444.

Pihlanto, L. 2000. Bioactive peptides derived from bovine whey proteins: Opioid and ACEinhibitory. Trends Food Science and Technology, 11: 347-356.

Qian, Z.-J., Jung, W.-K., Lee, S.-H., Byun, H.-G. \& Kim, S.-K. 2007. Antihypertensive effect of an angiotensin I-converting enzyme inhibitory peptide from bullfrog (Rana catesbeiana Shaw) muscle protein in spontaneously hypertensive rats. Process Biochemistry, 42(10): 1443-1448.

Qu, W., Ma, H., Pan, Z., Luo, L., Wang, Z. \& He, R. 2010. Preparation and antihypertensive activity of peptides from Porphyra yezoensis. Food Chemistry, 123(1): 14-20.

Quirós, A., del Mar Contreras, M., Ramos, M., Amigo, L. \& Recio, I. 2009. Stability to gastrointestinal enzymes and structure-activity relationship of beta-casein-peptides with antihypertensive properties. Peptides, 30(10): 1848-1853.
Rho, S.J., Lee, J.-S., Chung, Y.Il, Kim, Y.-W. \& Lee, H.G. 2009. Purification and identification of an angiotensin I-converting enzyme inhibitory peptide from fermented soybean extract. Process Biochemistry, 44: 490-493.

Sánchez-Rivera, L., Martínez-Maqueda, D., CruzHuerta, E., Miralles, B. \& Recio, I. 2014. Peptidomics for discovery, bioavailability and monitoring of dairy bioactive peptides. Food Research International, 63: 170-181.

Segura-Campos, M.R., Chel-Guerrero, L.A. \& Betancur-Ancona, D.A. 2011. Purification of angiotensin I-converting enzyme inhibitory peptides from a cowpea (Vigna unguiculata) enzymatic hydrolysate. Process Biochemistry, 46: $864-872$.

Tavares, T., Contreras, M.D.M., Amorim, M., Pintado, M., Recio, I. \& Malcata, F.X. 2011. Novel whey-derived peptides with inhibitory effect against angiotensin-converting enzyme: in vitro effect and stability to gastrointestinal enzymes. Peptides, 32(5): 1013-9.

Tsai, J.S., Lin, T.C., Chen, J.L. \& Pan, B.S. 2006. The inhibitory effects of freshwater clam (Corbicula fluminea, Muller) muscle protein hydrolysates on angiotensin I converting enzyme. Process Biochemistry, 41: 2276-2281.

Tsai, J.-S., Chen, J.-L. \& Pan, B.S. 2008. ACEinhibitory peptides identified from the muscle protein hydrolysate of hard clam (Meretrix lusoria). Process Biochemistry, 43: 743-747.

Wang, C., Song, W., Jiang, L. \& Du, M. 2014. Purification and identification of an ACEinhibitory peptide from walnut protein hydrolysate. European Food Research and Technology, 239: 333-338.

Wu, J. \& Ding, X. 2002. Characterisation of inhibition and stability of soy-protein-derived angiotensin I-converting enzyme inhibitory peptides. Food Research International, 35: 367375.

Wu, Q., Feng, Q., Zhi, C. \& Tao, P. 2015. Purification and characterisation of a novel angiotensin Iconverting enzyme inhibitory peptide derived from abalone (Haliotis discus hannai Ino) gonads. European Food Research and Technology, 240(1): 137-145. 
